\title{
GOTTHEIL, RICHARD JAMES HORATIO
}

(b. Manchester, UK, 1862; d. New York City, 1936), a prolific scholar, an important academic teacher and administrator, as well as an influential public intellectual.

GOTTHEIL, RICHARD JAMES HORATIO (b. 13 October 1862, Manchester, UK; d. 22 May 1936, New York City), a prolific scholar, an important academic teacher and administrator, as well as an influential public intellectual (FIGURE 1). Gottheil was professor of Semitic languages and rabbinical literature at Columbia University (1887-1936) and the first Chief of the Oriental Division of the New York Public Library (18971936).

Gottheil was one of the five children of the noted German reform rabbi Gustav Gottheil (1827-1903). He came to New York in 1873 when his father accepted the appointment as rabbi at the temple Emanu-El. Gottheil graduated from the Columbia College in 1881, and continued his education at the universities of Berlin, Tübingen, and Leipzig as well as at Jewish institutions in Berlin. Having received his Ph.D. from the University of Leipzig with a dissertation on Syriac grammar in 1886, he became lecturer in Syriac at the Columbia College, and was promoted to professor of rabbinical literature and the Semitic languages a year later. He held the first endowed chair of Jewish studies in the United States until his death in 1936. Gottheil was a colleague of the renowned Avesta scholar A. V. Williams Jackson (1862-1937; q.v. at www. iranica.com); both were Columbia alumni with a German Orientalist training. The history of how they together fostered the study of Semitic and Indo-Iranian languages in North America through establishing curricula at Columbia University and graduating students who in turn became professors at North American universities remains to be written (Van Amringe, pp. 278-79, 294-95; for Gottheil's students, see Greenspahn, pp. 211-13).

Gottheil's tenure at the New York Public Library (NYPL) is of relevance to the field of Iranian studies because he oversaw the development of its Near Eastern and Asian collections, first as Chief of Semitica and Orientalia (1897-1901), and afterwards as Chief of the Oriental Division. In 1895 the NYPL had received with the Astor Library an outstanding collection of books about Asia and Africa (Roehrig and Cogswell), and from 1897 to 1914 Gottheil could use the generous endowment of Jacob Schiff (18471920) to lay the foundation for one of the best Near Eastern studies collections world-wide. Although the Division's focus was on Arabic literature, Gottheil's catholic conception of the field is reflected in the range of topics for which, under his direction, Ida A. Pratt (employed by the NYPL 1901-42) compiled finding aids: from Assyria/Babylonia (1918) and ancient Egypt (1925 and 1942) to Persia (1915) and Armenia (1919), to Buddhism (1916) as well as to Arabic poetry (1908), Islamic law (1907), and modern Egypt (1929). The role of these specialized bibliographies for early 20th-century research cannot be overestimated, since they included articles and monographs, without the currently still common distinctions between Western/non-Western and primary /secondary sources, and could be searched by index and by topical arrangement. The works on Armenia (1919) and modern Egypt (1929) are further noteworthy because they were responses to contemporary politics: the 1915 Armenian massacres of the Ottoman Empire and the foundation of the Kingdom of Egypt in 1922.

The contents of the List of Works in the New York Public Library Relating to Persia (1915) reflect a remarkably inclusive approach to contemporary sources of Qajar Persia. Even though only a few pages are filled with works on biography (p. 49), commerce (pp. 50-52), and social Life (pp. 52-53), until the 1920 s Orientalist research adhered to the historicist dictum that historical research could not comprise the present (Gegenwartsgeschichte). The volume opens with short sections on bibliography (pp. 1-3) 
and periodicals (p. 4) to continue with the so-called Historischen Hilfswissenschaften: calendar (pp. 4-5), archeology (pp. 5-7), geology and natural history (pp. 7-8), and geography (pp. 8-25). The paucity of publications about art (pp. 54-57) and science (pp. 57-58) indicates that both art history and the history of science were fledgling disciplines. Yet the detailed sections on history (pp. 25-49), literature (pp. 5888), and religion (pp. 88-107), as well as the appendix on Jews in Persia (pp. 107-18) that had been compiled by Abraham S. Freidus (1867-1923), the Chief of the Jewish Division since 1901, document the wealth of available literature on Iranian civilization.

Gottheil accompanied this bibliography with a short introduction. He favorably compared Persian poetry to that in Hebrew and Arabic: "The old Hebrew may have been more stern in his demand for moral depth; the Arab more stately in his descriptions of desert life. The Persian touches us nearer to the bone" (p. v). And he detected in beaux arts sensibilities a fascination with Persian visual culture: "It is this art that has planted the rose-garden in our living rooms and has turned our carpets and our rugs from their prosaic use as utilitarian covers into pictures of nature, whose liveliness and freshness greet us all times of the year" (ibid.). This line of thought culminates in the claim that in the realm of religion, especially Zoroastrianism, Mithraism, and Sufism, Iran is so exceptionally important because "here ... the Semite and the Aryan met, taking the best from each one of his two forebears" ( $p$. vi). This hybrid conception of Iranian civilization has remained astonishingly avant-garde if seen against the background of the current organization of Arabic and Persian studies at Western universities.

After the bibliography's completion, Gottheil's interest in Iran and Persian literature did not dwindle. In 1932, he published the description of a newly acquired illustrated Šāh-nāma manuscript (NYPL, Spencer Pers. MS 2), which ever since has attracted great attention, although the illustrations are now considered 20th-century forgeries (Schmitz, pp. 105-11). Toward the end of his life, Gottheil was involved in the publication of the Ferdowsi (940-1019 or 1025; q.v.) memorial volume on the occasion of the millenary celebrations in 1935 (see FERDOWSĪ, in Elr IX, pp. 527-30). David Eugene Smith (18601944), a professor of mathematics and a famous book collector, recruited his Columbia colleagues Gottheil and Jackson for the Ferdowsi committee. Isaac Mendelsohn (1898-1965) collected information about manuscripts and imprints in Persian, as well as in translation, of the Šāh-nāma and Yusofo Zolaykā (Smith, pp. 27-138). While Gottheil, unlike Jackson, did not write a contribution, this volume was the last project for which he supervised the compilation of a bibliography.

\section{Bibliography:}

(Websites were accessed 7 July 2005.) For a selection of academic obituaries, see: Marianne Sanua, "Gottheil, Richard James Horatio," in American National Biography Online, Feb. 2000; available at http://www.anb.org/articles/08/08-01843.html. For a survey of Gottheil's publications, see: Ida A. Pratt, "Selected Bibliography of R. J. H. Gottheil," JAOS 56, 1936, pp. 480-89.

Gottheil's personal papers are kept in various depositories, the most important of which are the Klau Library of the Hebrew Union College in New York City; the American Jewish Archives in Cincinnati, Ohio; and the Central Zionist Archives in Jerusalem, Israel. Both Columbia University and the New York Public Library keep documents regarding Gottheil's employment and work in their institutional archives. For a 1919 photo of Gottheil with his NYPL colleagues, see Dain, New York Public Library, the unnumbered plates between pp. 160-61. In fall 1953, Gottheil's sister-in-law Eva Léon donated a painting and a photograph to the Zeta Beta Tau National Fraternity and the NYPL respectively. The painting can be

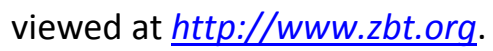


Works of Richard Gottheil. Persian Literature Comprising the Shah Nameh, the Rubaiyat, the Divan and the Gulistan, with a special introduction by Richard J. H. Gottheil, 2 vols., London and New York, 1900.

List of Works in the New York Public Library Relating to Persia, compiled by Ida A. Pratt, under the direction of Dr. Richard Gottheil, New York, 1915.

"The Shahnâmeh in Persian: An Illuminated and Illustrated Manuscript in the Spencer Collection," Bulletin of the New York Public Library 36, 1932, pp. 543-54 and 7 pls. "The Shahnâmeh in Turkish: An Illuminated and Illustrated Manuscript in the Spencer Collection," Bulletin of the New York Public Library 36,1932 , pp. $9-10$ and 2 pls.

Studies. Phyllis Dain, The New York Public Library: A History of its Founding and Early Years, New York, 1972, pp. 116-17; originally, Ph.D. diss., Columbia University, 1966.

E. Christian Filstrup, "The Oriental Division of the New York Public Library," UNESCO Journal of Information Science, Librarianship, Archives Administration 3/1, 1981, pp. 42-48.

Frederick E. Greenspahn, "The Beginnings of Judaic Studies in American Universities," Modern Judaism 20, 2000, pp. 209-25.

Morris Margulies, "Richard Gottheil," in Three Zionist Rishonim in America, New York, 1961, pp. 3-13.

Isaac Mendelsohn, "Near East Collections at Columbia," Columbia University Quarterly, Dec. 1940, pp. 283-99, for Gottheil pp. 292, 297.

Frederic L. O. Roehrig and Joseph G. Cogswell, Catalogue of Books in the Astor Library Relating to the Languages and Literature of Asia, Africa, and the Oceanic Islands, New York, 1854; lithographed. Barbara Schmitz, Islamic Manuscripts in the New York Public Library, New York, 1992.

David E. Smith, ed., Firdausi Celebration, 935-1935: Addresses Delivered at the Celebration of the Thousandth Anniversary of the Birth of the National Poet of Iran Held at Columbia University and the Metropolitan Museum of Art \& A Bibliography of the Principal Manuscripts and Printed Editions of the Shāh-nāmah in Certain Leading Public Libraries, New York, 1936.

John H. Van Amringe et al., A History of Columbia University: 1754-1904, New York, 1904.

Sam P. Williams, Guide to the Research Collections of the New York Public Library, Chicago, 1975, pp. 2934 for the Oriental holdings.

(Dagmar Riedel)

Originally Published: July 20, 2005 